\title{
ANOMIE IN ASHANTI?
}

\section{JACK GOODY}

$\mathrm{M}^{\mathrm{s}}$ ISS WARD, in her paper on Some Observations on Religious Cults in Ashanti, maintains that the spread of 'new witch-finding cults' in Ashanti results from an emotional malaise deriving from structural changes in the society. The hypothesis is one which has been put forward on other occasions to account for the reported increase in such activities. The basic propositions appear to be four: firstly, that major changes in the social system increase the overall malaise in a society : secondly, that such increased malaise will be reflected in an increase in witchcraft : thirdly, that an increase in witchcraft will be reflected in an increase in witch-finding cults: fourthly, that there has been such an increase in Ashanti.

The first two propositions raise general theoretical issues with which I do not wish to deal here, except to say that the problem of their proof is one which Durkheim tried to face and most other social scientists have tended to neglect. But I wish to comment on the last two in so far as Ashanti and Ghana are concerned. I submit that an increase in witch-finding cults is no indication of the incidence of witchcraft accusations, because it may be accompanied by a corresponding decrease in other ways of establishing the occurrence of witchcraft. Indeed, precisely this appears to have happened in Ashanti. According to Rattray, the Ashanti formerly practised the custom of ' carrying the corpse' at funerals. This custom was at one time widespread in Ghana and is still carried out in some of the more isolated parts. The movements of the corpse, carried aloft by two or more men, are held to indicate the agency which caused the death. The nature of these supposed agencies varies, but in Ashanti death appears frequently to have been attributed to a living member of the society. The movements of the corpse often in fact constitute a witchcraft accusation. (Rattray, 1927, p. 167.)

This custom has fallen into desuetude in most areas in Ghana, largely owing to the disapproval of the Administration and to other agencies of social change. Indeed it is now disapproved by a considerable section of the population. It is a most overt method of witch-finding; the accusation is virtually inescapable and the invitation to action strong. It would be hardly surprising if with the decline of the custom of 'carrying the corpse' other more covert forms of witch-finding were resorted to. Thus an increase in witch-finding cults does not necessarily imply an increase in witchcraft accusations, which surely must be the relevant criterion for establishing Miss Ward's thesis.

However, even if $\mathrm{I}$ am incorrect in maintaining that certain other witch-finding procedures are nowadays much more rarely used than formerly, an increase in the number and use of 'fetishes' or medicine shrines cannot in itself be taken as indicative of an increase in witch-finding activities. For, as Miss Ward herself points out, witchcraft is only one of the sins which such shrines forbid, discover, and perhaps punish. Sexual offences form another category so treated. Indeed there is no evidence in her published account that the scenes she witnessed were in fact confessions of

$$
\text { I Africa, Jan. 1956, pp. 47-61. }
$$


witchcraft; they might equally well have been confessions of adultery. Does Miss Ward believe that this also has increased since the arrival of the European?

I would go further and question whether there is any satisfactory evidence that an increase in the resort to medicine shrines has in fact taken place. Miss Ward assumes that this kind of cult was not formerly found in Ashanti. She regards the 'old cults' as being of three types: the cults of the royal ancestors, the cults of lineage ancestors, and the cults of the 'patrilineally inherited soul substance (ntoro)' which is also connected with certain state cults. In this scheme, which neatly interlocks with the most important social groups, there is no place for the medicine shrines, which are regarded as being recent imports. I would certainly agree that particular shrines are recent imports. I spent a year in the village in the Northern Territories containing the parent shrine of the Kpaykpaybia exported to Ashanti, which Miss Ward refers to as the 'very famous fetish at Kankamia near Kumasi' (p. 57).' But the establishment of a particular shrine as a recent arrival (Kpaykpaybia was, I believe, a relatively recent arrival in the village I lived in) does not establish that class of shrine as a new cultural feature. Indeed, reference to earlier accounts of the Ashanti will, I suggest, show firstly, that medicine shrines were by no means uncommon, secondly, that such shrines circulated between individuals and localities within Ashanti, and, thirdly, that they also migrated into Ashanti from outside, just as they do now.

The evidence for the existence of such shrines before the coming of the European is not easy to assess. We possess numbers of detailed accounts by Bowdich, Dupuis, Freeman, and others, but it is often difficult to decide precisely what kind of shrine or charm (if I may limit myself for the purpose of this discussion to the material object associated with the ritual) is intended by the word ' fetish'. It is, however, apparent that the referents of this word include a larger number of such categories than those selected by Miss Ward as characterizing the old religion. It is clear too that at least the last category she mentions, that is the obosom cults, were not as closely tied to the relatively enduring social groups as she seems to suggest. In other words, there appear to have been medicine shrines and there appears to have been a circulation of shrines.

To begin with the second of these points; although some obosom (' higher gods' in Rattray's phrase) were, as Ward states, associated with the non-localized patrilineal descent groups (ntoro) as well as with localities, they also circulated between such groups. Indeed, Rattray's account of the life of Komfo Anotche, who was the priest of Osei Tutu, first ruler of the kingdom, and who played a most important part in the founding of the state, shows that even 'the Ashanti Christ' was involved in the movement of these shrines. 'At Apa the villagers laughed at him when he wished them to adopt the god Aboasu as one of their deities' (1929, p. 272). Some time later, during the Ashanti-Domina wars, in the course of which the Ashanti state first emerged, he captured the ' spirit ' of the obosom, Tano, of a Domina priest, 'put it in a brass pan ' and appointed a custodian for it (p. 274). These acts were part of the process by which Domina was included in the Ashanti state. The same account gives some evidence not only for the circulation of shrines but also for their invention. Indeed, the Golden Stool itself might be considered a case in point. But more particularly there is Anotche's quest for a medicine against death and the establishment at Agona,

I The shrine is, I believe, situated at the village of Kwapera some six miles from Kumasi. 
where he died, of the shrine Boboduru, which Rattray describes as ' Komfo Anotche's obosom'.

I have attempted here to isolate references to the category obosom and to give some evidence of the circulation of such obosom. But the word 'fetish' has a wider reference than this. There is another category of 'personal' shrines and charms, one which Ward does not mention, known as suman. There are two points in Rattray's account of these to which I want to draw attention. Firstly, his whole discussion shows that the boundary between obosum and suman is by no means distinct. During his visit to the Tano shrine, for example, he encounters 'the priest of a god, who I much suspect was an elevated suman' (1923, p. 159). Secondly, some of these suman were concerned with the detection of witchcraft. Rattray ( 1927, P. 3I) gives an account of the 'famous fetish Fwemso' a very elaborate fetish which formerly had its headquarters at Lake Bosomtwe and was used 'for the purpose of discovering witches'. This shrine was apparently difficult to distinguish from the 'orthodox abosom', for it had its own temples and its own men and women attendants. Moreover, the shrine was imported. 'This fetish, in common with several others, I believe, was not of pure Ashanti origin, having been introduced from Apollonia.'

There can be no doubt that this type of shrine existed in Ashanti before the coming of the European and the beginning of the malaise due to this 'culture contact'. For included under this term suman are the Moslem safi, charms which included fragments of paper inscribed with Arabic letters (Rattray, 1927, Pp. 20-21). These safi, although coming from a foreign culture, were nevertheless of considerable importance to the Ashanti. Bowdich (ed. 1873, p. 223) writes, 'But the most surprizing superstition of the Ashantees is their confidence in the fetishes or saphies they purchase so extravagantly from the Moors, believing firmly that they make them invulnerable and invincible in war, paralyze the hand of the enemy, shiver their weapons, divert the course of balls, render both sexes prolific, and avert all evils but sickness (which they can only assuage) and natural death. The King gave to the King of Dagwumba for the fetish or war coat of Apokoo the value of thirty slaves.... Several of the Ashantee captains offered seriously to let us fire at them.'

Moreover, the class of suman includes not only the Muslim charms but also the medicine shrines such as those which have recently migrated from the North. Indeed, the shrine Kunkuma which, according to Rattray in 1927, was regarded as the 'greatest suman in Ashanti' may well be the Kankamia mentioned by Ward. Nor is there any reason to believe that this circulation is new. If Muslim charms came down from Dagomba, which was not in fact a Muslim state, at the beginning of the nineteenth century, then there seems little doubt that medicine shrines came as well. We have seen that shrines of certain kinds, namely the suman and obosom, circulated within Ashanti. Secondly, we know that there were relationships both of trade and war between Ashanti and the North. Recent work in the adjacent Kingdom of Gbanya (Gonja) in the North has shown me that there was also ritual collaboration, at least between Gbiipe in Gbanya and Nkoranza in Ashanti, both towns situated on a main trade route from Kumasi. Thirdly, the accounts of Dupuis and Bowdich indicate that the slave population of Ashanti must have been considerable; these were mostly inhabitants of the Northern Territories, captured in war or contributed by way of tribute, and would undoubtedly have established their own shrines. 
One of the most striking pieces of evidence of the circulation of shrines of the ' medicine ' type between Ashanti and the Northern Territories is given by Freeman in his account of his voyage to Bonduku in 1889 (Freeman, 1898 ). On reaching Odumasi in the north-west, his party was greeted by a fetish dance. 'The deity worshipped was the great inland fetish, Sakrobundi, or Sakrobudi, whose "sphere of influence " appears to be very extensive, including Jaman, Gruinsi and several of the countries lying to the north.... It appeared, however, that the worship of Sakrobundi had been introduced into Jáman from the north-possibly from Gruinsi, Moshi, or Dagomba-in comparatively recent times' (p. I48).

These points concerning Ashanti religion can be elucidated by reference to my own fieldwork. In the north-western corner of Ghana the traditional mode of life has perhaps changed as little as in any other area of Africa. The 'old cults' associated with the Earth and the ancestors flourish, but they exist side by side with an efflorescence of medicine shrines. It is true that there too the inhabitants will say of such and such a shrine, 'That's new. We didn't have that in the old days. But then we didn't need them then. Not so many bad people about.' Such statements have often been brought forward as indices of worsening conflict situations under contact with other societies. But can they stand up to such an interpretation?

In the Northern Territories of Ghana, contact with Europeans dates back not more than fifty years, so it is still relatively easy to gain information about the period before they arrived. I have many times heard the story of how the British troops came to the village mentioned above, and how the inhabitants, hearing of their approach and of the number of guns they carried, sought in a settlement some miles away a medicine (tiii) from a shrine (tiib) which was supposed to give protection against the white man's bullets. The shrine was acquired by certain individuals in the usual way they are today and set up in their compounds. When the white man came, the shrine and its associated medicine were tried out and, after a couple of severe casualties, were recognized as ineffective. The settlement submitted to alien rule and the particular medicine shrines fell into decay.

This incident highlights two important points. Firstly, the inhabitants tend to deny the existence of such shrines in the past, despite the fact that these certainly existed. Secondly, though medicine shrines have endured as a class, particular shrines disappear and new ones arise. Indeed, they are constantly coming into being. A somewhat eccentric acquaintance of mine, generally supposed to be in touch with the fairies (the hill and water sprites), created three entirely new ones in quite a short space of time. But whether such creations become widely employed, and enter into the circulation of shrines, is quite another matter. These shrines then are always waxing and waning in importance. That they do so is an indication of how loosely they are tied up with the system of social groups, a fact which possibly indicates why it is that old men sometimes say that they were not so important formerly, and why sociologists may be inclined to overlook them in their published accounts. One shrine becomes successful, another fades out. The inhabitants are very pragmatic about such things, as well as eclectic. If one shrine appears to be effective, they take it up. If it fails them, they drop it. The next man's shrines, whatever 'faith ' he may profess, are as good as one's own; better, if they are more successful.

I am aware that there is always a danger of trying to assimilate neighbouring 
peoples to the pattern of the particular group with which one is acquainted. However, there seems to me a possibility, which is confirmed by my reading of the ethnographic material, that analysis of the ritual institutions of the Ashanti and other African peoples has failed to allow for the established mobility of such shrines. I do not doubt that such mobility has increased with the increase in spatial mobility of the inhabitants. But I cannot agree that it is a feature new to West Africa. There has been a considerable interchange of persons among different social groups through the long-established methods of trade and war, and particularly through the slavetrade, which was sometimes war and sometimes trade. Such intercourse led to an interchange of ritual techniques and services long before European contact became of major significance. This is apparent from Bowdich's account of the activities of the 'Moors' in Kumasi in the early years of the nineteenth century; Moslems had an established position in the society and their titual techniques were used on important occasions. Although the pace of such intercourse may have gathered momentum, there is insufficient evidence to demonstrate that the mortality rate among these shrines has not also increased. But quite apart from the question of increase, the suggestion that such cults are a new feature of Ashanti life is surely questionable. I have already mentioned some examples from previous authors. I know myself of one such cult which is said to have migrated, together with its practitioners, from Techiman to Gonja about a century ago, that is to say in the opposite direction. Would it not therefore be more accurate to interpret Fortes's phrase 'new witch-finding cults' as referring to the particular cults rather than to the type of cult?

My discussion of Ashanti cults contains two general implications, one of which concerns the analysis of ritual institutions in general and the other the study of changing conditions.

Since Durkheim, sociologists have tended to regard a particular ritual institution as 'explained' once it has been firmly linked with a social group. Relevant as this type of explanation may be in many instances, it omits a range of institutions of which Ashanti medicine shrines are a particular example. Throughout Ghana the clients of a shrine other than an ancestor shrine or an Earth shrine do not necessarily belong to a specific social group, though the shrine may also have a permanent congregation. The Tallensi shrines in the Tong Hills are a case in point; Rattray's prayer that the shrine should assist him to make the first solo flight to the Gold Coast was not incongruous in terms of indigenous social institutions (Rattray, 1932, p. 361). Medicine shrines are established features of the area, not recent anomalies. They are available to clients from other parts, not least because these ritual services are exchanged for goods and services of different kinds. This provision of ritual services may have political implications, but I am here concerned with two other aspects: the consequences firstly for the system of religious constructs and secondly for the economic system. The confidence which the Ashanti captains derived from their safis cannot, as we see from one LoWiili example, be invariably sustained. Events may prove overwhelming and threaten faith. But there are a number of ways in which the potential disillusionment may be circumvented. A common procedure is to attribute the false prophecy to the actor's failure to comply with the prescriptions of the shrine in question. He has failed to observe the ritual prohibitions and by his sin has forfeited the support of the supernatural agency. This type of explanation is familiar to 
Christians and Moslems. Rattray (1929, pp. 273-4) recounts how Komfo Anotche explained a false promise of victory by countering that one of the Ashanti generals had disregarded a taboo. An alternative, for obvious reasons not found in monotheistic religions, is a rejection of the shrine in question and the resort to another supernatural agency. This appears to me to be one aspect of the mobility of medicine shrines in West Africa; they are gods who have failed.

Another aspect is the economic one. The trade in safis was clearly a brisk one in the early nineteenth century, for Bowdich observed that in Kumasi a sheet of paper would keep a Moslem for a month (p. 223). This may not be comparable to the wealth obtained by the custodians of the Tong Hill shrine nor yet the owners of the Kumasi Kpankpanbia, but we have to take into account the increased flow of goods and services since that time. Indeed, the increase in ritual activity may be partly accounted for by the increased wealth available. 'Masses for the Dead' are clearly one way of disposing of surplus wealth -a ritual potlatch. It is apparent from Rattray's and earlier accounts of Ashanti that there was sufficient surplus of production over consumption to maintain some specialists who had no other functions than to perform ritual services.

The above comments do not constitute an attempt to see religious institutions as ' determined ' by the economic system. They are concerned only with the economic aspects of certain religious institutions. I would add that, while recent writers on African religion, such as Evans-Pritchard and Nadel, have made notable contributions to the study of primitive religions as such, they have tended to neglect this particular aspect. It seems unfortunate that the functionalist emphasis on the interlocking of the various institutional complexes in the social system should have had so much less influence in the study of primitive religion than in any other field.

The other general point implied in my criticism concerns studies of social change and in particular the tendency of sociologists to adopt a doctrine of 'increasing misery 'as the result of contact with a mercantile or industrial economy. Assumptions of increasing or decreasing tension clearly require validation over time. In most of the cases considered by anthropologists little time depth can be added. But for Ashanti the records are good and have tended to be neglected, perhaps as the result of the insistence of some functionalists that all historical evidence is irrelevant to structural studies. But clearly reasonable hypotheses about past conditions are in fact essential to an analysis of 'trends'. What most anthropologists do is either to reconstruct past conditions from the tales of old men or else to assume that village $A$ represents a more traditional state of affairs than village $B$. But clearly these techniques are of limited value, particularly as they tend to lead to 'Golden Age 'assumptions of a stable past and an unstable future. The assumption of a social structure which has continued unchanged over time is often a case where actor categories have been taken over by the anthropologist for want of any better information. E. R. Leach makes a similar point in Political Systems of Highland Burma (1954). But despite his criticism of the hypothetical nature of the assumption of stable equilibrium, his own analysis of the Kachin attempts to establish a cyclical equilibrium of a much more conjectural order. I am not rejecting the assumption of stability as a heuristic device in the absence of other information. But for the Ashanti we have better information. It would be wrong, for example, to analyse the Ashanti state as if it had 
continued in its present form since the time it first came into existence. It would also be incorrect to assume that the social organization had not been profoundly affected by the ending of slavery both of the domestic and plantation kind. For these changes evidence exists; changes in emotional states cannot be so easily assessed. If one is to rely on the evidence of European travellers as to the former incidence of slavery, execution, and watfare, one cannot maintain that there has been an increase in malaise over the last fifty years. Clearly the British occupation in many ways brought an increased rather than a decreased personal security.

My criticism that the 'new witch-finding cults' provide an unsatisfactory index of an increase in individual anxieties in Ashanti is therefore relevant not only to this one case but also to other interpretations of the 'clash of cultures' elsewhere in Africa and the world. We have as yet no euphorimeters. The happiness ratio of one population as against another is difficult to establish, even keeping constant the time or space variable. Yet sociologists and anthropologists appear to be increasingly committed to a hypothesis that culture change increases 'individual anxieties', ' emotional malaise '. Is this not as dubious as Marx's doctrine of increasing misery under a capitalist economy? And is it not immediately suspect as a possible rationalization of the social scientist, sociologist, or psychologist, resulting from his vested interest in stable phenomena?

Quite apart from the question of the validity of Miss Ward's criteria, there seems to me to be little basis for an increase in malaise in Ashanti. Clearly there is a situation of rapid change. But to view this process, as sociologists have tended to do, as leading to anomie (normlessness) is in fact to make a value judgement regarding the course of that change on what would appear to be inadequate evidence. I would argue that this assumption is unproven and that further progress is unlikely to be made on an impressionistic level. That it should be understood to be unproven seems to me important not only on the theoretical plane but also for those engaged in social engineering.

Bowdrch, T. E. 1819. Mission from Cape Coast Castle to Ashantee (ed. 1873), London.

DupuIs, J. I824. Journal of a Residence in Ashantee, London.

Fremman, R. A. 1898. Travels and Life in Ashanti and Jdman, London.

Goody, J. R. I956. The Social Organization of the LoWiili, London.

RaT'Tray, R. S. I923. Ashanti, Oxford.

- 1927. Religion and Art in Ashanti, Oxford.

- 1929. Ashanti Law and Constitution, Oxford.

-1932. The Tribes of the Ashanti Hinterland, Oxford.

\section{Résumé}

\section{L'ANOMIE DANS L'ACHANTI?}

DANS une communication récente, ${ }^{\mathrm{I}}$ Mademoiselle Ward maintient que la propagation dans l'Achanti des cultes pour la recherche des sorcières résulte d'un malaise émotif qui découle des modifications structurelles au sein de la société. Les suppositions fondamentales d'une telle hypothèse paraissent être au nombre de quatre; $\mathrm{I}^{\circ}$, que les modifications majeures dans le système social augmentent le malaise général dans une société; $2^{\circ}$, qu'un tel malaise accru se manifestera par un accroissement de la sorcellerie; $3^{\circ}$, qu'un accroissement de la

"Voir Africa, Jan. 1956, pp. 47-61. 
sorcellerie se manifestera par un accroissement des cultes pour la recherche des sorcières; $4^{\circ}$, qu'un tel accroissement a eu lieu dans l'Achanti. C'est au sujet de ces deux dernières suppositions que l'auteur de cet article désire faire des commentaires en ce qui concerne l'Achanti et Ghana. A son avis, un accroissement des cultes pour la découverte des sorcières n'est pas une indication de l'incidence des accusations de la sorcellerie, car il peut être accompagné d'un décroissement correspondant dans d'autres moyens d'établir l'existence de la sorcellerie. C'est ce qui paraît avoir eu lieu dans l'Achanti où une méthode évidente de rechercher des sorcières - la coutume autrefois largement répandue de 'transporter le cadavre' lors des enterrements et de deviner la cause du décès d'après ses mouvements - n'est plus pratiquée. Une augmentation dans le nombre et l'utilisation de 'fétiches' et d'autels de magie ne saurait être regardée comme étant, par elle-même, une indication d'un accroissement des activités dans la recherche des sorcières, car la sorcellerie n'est qu'un seul des péchés défendus, découverts ou punis par de telles méthodes. Il est douteux s'il y a eu un accroissement dans la fréquentation des autels de magie, qui, d'une façon générale, ne sont pas nécessairement des importations nouvelles. Le mot 'fétiche' peut également comprendre des autels et des amulettes 'personnels', dont certains se rapportaient à la décou-

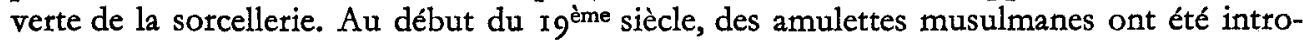
duites du nord et il paraît presque certain que les autels de magie ont été introduits de la même façon. Dans les Territoires Septentrionaux de Ghana, le contact avec les Européens ne date que depuis une cinquantaine d'années, tout au plus, et, par conséquent, il est relativement facile d'obtenir des renseignements concernant la période avant leur arrivée. Les habitants ont tendance à nier l'existence des autels anciens qui sont tombés en ruines et qui ont été remplacés par d'autres plus efficaces, ce qui indique le faible lien qui les rattache au système des groupes sociaux. L'analyse des institutions rituelles des Achantis et des autres peuples africains n'a pas tenu compte de la mobilité reconnue de tels autels qui, naturellement, s'est accrue avec la mobilité spatiale croissante des habitants. En effet, il y a toujours eu un échange considérable de personnel en Afrique Occidentale parmi les différents groupes sociaux par suite de la guerre et du commerce, notamment le commerce des esclaves. La liaison d'institutions rituelles particulières avec certains groupes sociaux ne s'applique pas aux autels de magie des Achantis qui, malgré leurs assemblées permanentes de fidèles, sont également disponibles à des clients d'une autre provenance en échange de diverses marchandises ou services. Ainsi, l'accroissement de l'activité rituelle peut être attribuée en partie à la richesse accrue qui est disponible. On ne peut admettre que l'état Achanti ait continué dans sa forme actuelle depuis le moment de son premier établissement ou qu'il y ait eu un accroissement de malaise au cours de ces cinquante dernières années. Il est évident que l'occupation britannique a produit une augmentation plutôt qu'une diminution de la sécurité personnelle. Il existe, bien entendu, une situation de changement rapide, mais il n'y a pas d'évidence suffisante pour indiquer que ce changement conduit à l'anomie (manque de normes) et il importe qu'il soit clairement reconnu que ce point n'a pas été prouvé. 